\title{
ANTHROPOMETRY AND BIOELECTRICAL IMPEDANCE ANALYSIS COMPARED TO DUAL-PHOTON ABSORPTIOMETRY FOR THE ASSESSMENT OF BODY COMPOSITION OF HIV-SEROPOSITIVE PATIENTS
}

\section{ANTROPOMETRÍA Y ANÁLISIS DE IMPEDANCIA BIOELÉCTRICA COMPARADO CON ABSORCIOMETRÍA FOTÓNICA DUAL PARA LA EVALUACIÓN DE LA COMPOSICIÓN CORPORAL EN PACIENTES INFECTADOS POR VIH}

\author{
Rebeca Antunes Beraldo, Helena Siqueira Vassimon, Alceu Afonso Jordão J., Francisco José de Albuquerque, \\ Alcyone Marchioli Machado, Maria Cristina Foss de Freitas, Anderson Marliere Navarro. \\ Department of Internal Medicine \\ Faculty of Medicine of Ribeirão Preto, University of São Paulo FMRP-USP. Sao Paulo, Brasil.
}

\begin{abstract}
Introduction: HIV-seropositive patients have shown changes in body composition such as lipoatrophy in certain regions of the body and lipohypertrophy in others, representing characteristics of lipodystrophy syndrome. It is important to monitor the quantity of fat per body segment using practical and low-cost methods in order to optimize the treatment of this group. Objectives: To correlate the body composition per body segment obtained by anthropometric measurements and by segmental bioelectrical impedance with DXA in HIV-seropositive patients on antiretroviral treatment Methods: We measured circumferences (arm, waist, hip, thigh and calf) and skinfolds (biceps, triceps, subscapular, suprailiac) and performed segmental bioelectrical impedance (BIA) analysis and DXA. The Pearson test was used to determine correlations and the St. Laurent test was used to assess concordance between variables. Results: We evaluated 26 patients, 35\% of whom were overweight. The triceps skinfold (TSF), waist circumference (WC) and thigh circumference (TC) were significantly correlated with the measurement obtained by the gold standard $(p<0.01)$. There was no concordance between the values obtained by segmental BIA and by DXA. Conclusions: Anthropometric measurements such as TSF, WC and TC are important for the monitoring of changes in body composition among HIV-seropositive patients on antiretroviral treatment. Segmental BIA did not prove to be appropriate for the assessment of body composition in HIV-seropositive patients.
\end{abstract}

Key words: anthropometry; segmental bioelectrical impedance, lipodystrophy, HIV.

Este trabajo fue recibido el 5 de Julio de 2011 y aceptado para ser publicado el 8 de Septiembre de 2011.

\section{INTRODUCTION}

Scientific advances such as the development of serological tests for HIV infection and the increase knowledge about molecular virology, epidemiology and pathogenesis of the virus, as well as improved efficiency of highly active antiretroviral therapy (HAART), have been admirably implemented since the discovery of the disease in 1984 (1).

Despite its benefits, HAART has specific types of toxicity such as elevation of serum total cholesterol and triglyceride levels, reduction of high-density lipoproteins (HDL), alterations in the distribution of body fat, increased insulin resistance and diabetes, with all of these changes representing risk factors for cardiovascular disease (2). This set of changes is denoted lipodystrophy syndrome $(3,4)$. This syndrome involves changes in body composition and in adipose tissue distribution, changes in lipid metabolism (dyslip- 
idemia) and/or changes in glycid metabolism (insulin resistance), in contrast to the changes occurring before HAART, when the patients had cachexia and higher mortality rates (5).

The alteration of adipose tissue consists of two processes, i.e., lipoatrophy and lipohypertrophy. Lipoatrophy involves a loss of subcutaneous adipose tissue that typically occurs in the extremities, buttocks and face, while lipohypertrophy mainly occurs in the visceral compartment of the abdomen, in breast tissue in women and less commonly among men, and, even more rarely, in the dorsocervical area (6).

The determination of body composition is of great importance in clinical practice, mainly due to its association with the various metabolic changes $(7,8)$ that also occur in patients using HAART $(9,10)$. Methods such as computed tomography, magnetic resonance, DXA and hydrostatic weighing produce accurate results but their cost is high and they are not available at most institutions.

In contrast, skinfold (SF) and biolelectrical impedance (BIA) techniques are considered to be simple, of more accessible cost and noninvasive for the estimate of body composition and therefore their use has attracted important attention in the literature (11).

BIA has shown a great potential for the estimate of body composition. The BIA instrument is portable, safe and noninvasive and yields rapid and reproducible results $(12,13)$. The resistance and reactance values obtained by BIA can be used to estimate body composition based on predictive equations, such as that of Kotler (14).

According to these same principles, a great innovation in the analysis of body composition is segmental BIA. This method permits an accurate prediction of body composition by means of measurements of length and resistance of some body segments such as the arm, leg and trunk (15). The equations elaborated for healthy individuals are not appropriate for patients with certain diseases and therefore they should be specifically validated for the group of HIV-1-infected patients (16).

In view of the high prevalence and consequences of the changes in body composition of HIV-seropositive patients on HAART, and considering that no validated practical and low-cost method for the monitoring of these changes exists in the literature, it is important to compare practical and accessible methods such as anthropometry and BIA to more precise methods which, however, are of difficult clinical applicability such as DXA.

Thus, the objective of the present study was to assess the correlation and concordance of anthropometric and segmental BIA measurements with DXA in HIVseropositive patients on HAART.

\section{PATIENTS AND METHODS}

The study was carried out at the University Hospital, Faculty of Medicine of Ribeirão Preto (HC/FMRP). HIV+ individuals were selected at the Dyslipidemia Outpatient Clinic and at the Immunodeficiency Syndrome Outpatient Clinic, both belonging to the Specialized Unit for the Treatment of Infectious Diseases of the same hospital.

The study was approved by the Research Ethics Committee and all subjects gave written informed consent to participate.

The inclusion criteria were: stable HIV-seropositive patients on HAART for at least six months, CD4 T-cell count of more than 200 cells/mm3; undetectable viral burden; age between 18 and 60 years; stable weight ( $<$ $10 \%$ change in the last year), and BMI between 18.5 and $30 \mathrm{~kg} / \mathrm{m}^{2}$.

The exclusion criteria were: presence of edema; changes in thyroid function; severe changes in different systems (renal, cardiac, pulmonary and hepatic systems); signs or symptoms of opportunistic infections, and presence of a pacemaker or metal prosthesis.

A protocol was elaborated to obtain information about schooling, use of hypoglycemic and lipid-lowering medications, alcohol drinking, smoking, use of illicit drugs, information about the antiretroviral drugs currently being used, biochemical exams (viral burden, CD4 T-cells, lipid profile, and glycemia), and diagnosis obtained from the medical records.

All patients in the Dyslipidemia Outpatient Clinic and at the Immunodeficiency Syndrome Outpatient Clinic for the period of March to October 2011 who fit inclusion criteria were invited to participate in the study, but only a small number (26 subjects) accepted. This was due to the unavailability of patients' time for the examination of DXA.

\section{Criteria for the definition of lypodystrophy syndrome}

Subjective. Report of fat loss or accumulation in specific regions of the body, confirmed by the physical examination performed by the investigator. Lipodystrophy is considered to be present when lipoatrophy is detected in at least one site, i.e., loss of visible fat in peripheral regions (arms, legs or face) accompanied or not by lipohypertrophy, i.e., fat accumulation in an abdominal region, dorsal gibbosity or gynecomasty (17).

Objective. In combination with the subjective criteria, we used the ratio of trunk fat percent to lower limb fat percent (Bonnet index). Lipodystrophy is considered to be present when the value of the index is 1.5 or more (18). 


\section{Body weight and height}

Body weight in $\mathrm{Kg}$ was measured in the Flizola eletronic scale platform type, with a maximum capacity of $300 \mathrm{~kg}$ and precision of $0.1 \mathrm{~kg}$. Subject was wearing clothes and shoes, being asked to withdraw jackets and coats, if present.

Height was measured with a stadiometer accurate to $0.1 \mathrm{~cm}$, with the subject barefoot, with arms at your sides and heels togheter touching the vertical rod and positioned at the center of the product.

\section{Body composition per segment}

The hologic instrument model QDR 4500W® was used for DXA by a specifically trained technician, with standard procedures being used to position the individuals during the execution of the exam. The individuals were first instructed to remove all metal objects, shoes and clothes and then to lie in dorsal decubitus on the apparatus. The screening was obtained by transverse scans from the head to the feet and the images obtained were processed with the most recent software of the system, version 11.2:5 for Windows. The results provided muscle mass, fat mass and muscle mass plus bone content values in grams, in addition to whole body fat percent. The results were obtained per body region, i.e., legs, arms and trunk.

Arm (AC), waist (WC), hip (HC), thigh (TC) and calf (CfC) circumferences were measured according to the standardization of Lohman et al. (19).

The tricipital (TSF), bicipital (BSF), subscapular (SSF) and suprailiac (SISF) skinfolds were measured with a Lange Skinfold Caliper ${ }^{\circledR}$ adipometer (Beta Technology Incorporated, Cambrige, MD, USA) according to the standardization proposed in the manual of Lohman et al. (19). Arm muscle area (AMA) and arm fat area (AFA) were calculated (20).

The values obtained were compared to the reference work of Frisancho (21) for the 50th percentile by means of percent adequacy.

Segmental BIA was performed using the length of the limb and appropriate electrode positioning, with resistance and reactance values being obtained for each segment of the arm, leg and trunk.

The following anatomical positions were used to measure the lengths:

Arm: arm length was calculated from the distal-most point of the third metacarpus to the acromion, with the arm fully extended (22).

Trunk: trunk length was calculated by the difference between the height measured from the acromion minus the length of the leg (23).

Leg: the length of the leg was calculated as the dif- ference between total height and sitting height (23). The following anatomical points were used for electrode placement:

Arm: a pair of electrodes was placed in the standard position, i.e., one electrode on the hand and the other at a distance of $5 \mathrm{~cm}$ from the wrist, and the other pair was placed on the acromial process and in the axillary fold (22).

Trunk: the first pair of electrodes was placed on the anterior midline of the proximal thigh, with the "receiving" electrode on the same plane as the gluteal fold and the "source" electrode on the anterior midline of the neck $5 \mathrm{~cm}$ from the skull (23).

Leg: a pair of electrodes was placed on the anterior midline of the proximal thigh and the other was placed in the standard position, with one electrode on the ankle and the other on the foot at a distance of $5 \mathrm{~cm}$ (23).

The predictive equations used were those validated by Baumgartner and Chumlea $(22,23)$.

\section{Statistical analysis}

All continuous variables are presented as means $+\mathrm{SD}$ and the categorical variables are reported as frequencies and percentages. The correlation between continuous variables was calculated by the Pearson test considering normal distribution (Kolmogorov-Smirnov test). The concordance test (only among male patients) used for the continuous variables considering DXA as the reference method and the St. Laurent test (24) was applied. The analyses were performed using the SAS/ STAT software, version 9 2002-2003 (25).

\section{RESULTS}

Twenty-six patients were evaluated, twenty of them (76.9\%) were males and mean patient age was $48.6 \pm$ 8,6 years. Mean time since the diagnosis of HIV infection was $12.5 \pm 4.6$ years and mean duration of HAART was $11.3 \pm 3.3$ years. Regarding the biochemical exams, cholesterol, TG and glycemia levels were above normal values and HDL levels were below normal values (table 1).

Table 1 lists all the anthropometric measurements performed. Regarding BMI, $34.6 \%$ of the subjects were overweight and $42.3 \%$ presented an increased abdominal circumference.

Of the subjects studied, 23.0\% had diabetes mellitus, 96.1\% had dyslipidemia, 38.4\% had systemic arterial hypertension, $34.6 \%$ were overweight, $26.9 \%$ were smokers, $7.7 \%$ used illicit drugs, $26.9 \%$ were alcoholics, $50.0 \%$ used lipid-lowering medications, and $30.7 \%$ used glycemia-lowering drugs. 
Of the patients, $26.9 \%$ reported the practice of physical activity with a duration of less than 10 minutes per day, 38.4\% reported a duration of 10 to 30 minutes per day, and $34.6 \%$ a duration of more than 30 minutes per day.

Table 2 lists the subjective and objective data for the classification of lipodystrophy syndrome according to body composition. It should be pointed out that, on the basis of subjective evaluation, $69.3 \%$ of the patients had leg lipoatrophy and 80.7\% abdominal lipohypertrophy. Subjective evaluation detected a greater percentage of individuals with lipodystrophy (96.1\%) compared to objective evaluation (69.3\%) (Bonnet index) (table 2).

The adequacy of the anthropometric measuraments was calculated with the 50th percentile of the reference values in percentile tables presented by Frisancho (21). Most of subjects had less than 70\% adequacy of TSF and AFA (73.0\% and 76.9\%, respectively) (table 3), which indirectly reflects a smaller quantity of fat in the arm region. Of these patients with less than $70 \%$ adequacy of TSF and AFA, $31.5 \%$ and $30.0 \%$ were below the $5^{\text {th }}$ percentile.

\section{TABLE 1}

General and anthropometric characterization of the study group.

\begin{tabular}{|c|c|}
\hline Variables & Mean \pm SD $(n=26)$ \\
\hline Age (years) & $48.6 \pm 8.6$ \\
\hline Time of positive serology (years) & $12.5 \pm 4.6$ \\
\hline Time of HAART (years) & $11.3 \pm 3.3$ \\
\hline T CD4 cells (cells/mm³) & $669.4 \pm 368.2$ \\
\hline Total cholesterol (mg/dl) & $212.3 \pm 52.3$ \\
\hline Triglycerides (mg/dl) & $277.8 \pm 154.9$ \\
\hline High-density lipoprotein (mg/dl) & $38.6 \pm 9.8$ \\
\hline Low-density lipoprotein (mg/dl) & $118.9 \pm 35.2$ \\
\hline Glycemia (mg/dl) & $103.8 \pm 44.1$ \\
\hline Current weight (kg) & $65.1 \pm 11.0$ \\
\hline Height (cm) & $164.0 \pm 8.2$ \\
\hline BMI $\left(\mathrm{kg} / \mathrm{m}^{2}\right)$ & $23.9 \pm 2.8$ \\
\hline $\mathrm{AC}(\mathrm{cm})$ & $28.4 \pm 3.9$ \\
\hline WC $(\mathrm{cm})$ & $90.5 \pm 7.5$ \\
\hline $\mathrm{HC}(\mathrm{cm})$ & $89.9 \pm 7.4$ \\
\hline ThC (cm) & $47.8 \pm 5.1$ \\
\hline CPant (cm) & $33.7 \pm 2.9$ \\
\hline TSF (mm) & $8.3 \pm 4.6$ \\
\hline BSF (mm) & $9.4 \pm 4.9$ \\
\hline $\mathrm{SSF}(\mathrm{mm})$ & $15.3 \pm 5.1$ \\
\hline SISF (mm) & $15.3 \pm 8.8$ \\
\hline $\operatorname{AMC}(\mathrm{cm})$ & $25.5 \pm 3.3$ \\
\hline WHR & $1.01 \pm 0.06$ \\
\hline $\mathrm{AFA}\left(\mathrm{cm}^{2}\right)$ & $12.5 \pm 6.2$ \\
\hline
\end{tabular}

HAART: highly active antiretroviral therapy; BMI: body mass index; AC: arm circumference; WC: waist circumference; HC: hip circumference; ThC: thigh circumference; CC: calf circumference; BSF: bíceps skinfold; TSF: triceps skinfold; SSF: subscapular skinfold; SISF: suprailiac skinfold; AMC: arm muscle circumference; WHR: waist/hip ratio; AFA: arm fat area; ad: adequacy. 
Considering the reference values for waist circumference (WC) is less than $94 \mathrm{~cm}$ for males and less than $80 \mathrm{~cm}$ for females, and reference values for waist/hip ratio (WHR) is less than 1.0 for males and less than 0.85 for females, $42.3 \%$ e $65.3 \%$ of the subjects had increased values of WC and WHR, respectively.

Table 4 shows that various anthropometric measurements (TSF, WC and TC) are correlated with the amount of fat determined by DXA.

No concordance was detected between fat values per limb obtained by DXA and the values obtained by segmental BIA (table 5).

\section{DISCUSSION}

The objective of the present study was to determine whether the instruments used in regular clinical practice would be appropriate for the assessment of the changes in body composition experienced by HIV-seropositive patients with lipodystrophy syndrome.

In the present study, based on BMI, 34.6\% of the subjects were found to be overweight. Boskurt et al (26) stated that the overweight of this group of patients

TABLE 2

Presence of lipoatrophy and lipohypertrophy per body region according to the diagnostic criterion $(n=26)$.

\begin{tabular}{lcc} 
& $\mathbf{n}$ & $\mathbf{\%}$ \\
\hline Subjective & & $57.7 \%$ \\
Lipoatrophy of the arms & 15 & $69.3 \%$ \\
Lipoatrophy of the legs & 18 & $65.3 \%$ \\
Lipoatrophy of the face & 17 & $80.7 \%$ \\
Lipohypertrophy of the abdomen & 21 & $23.0 \%$ \\
Dorsocervical lipohypertrophy & 6 & $0 \%$ \\
Lipohypertrophy of the chest & 0 & $11.5 \%$ \\
Lipohypertrophy of the breasts & 3 & $11.5 \%$ \\
Isolated lipoatrophy & 3 & $15.3 \%$ \\
Isolated lipohypertrophy & 4 & $96.1 \%$ \\
Subjectively evauated lipodystrophy & 25 & $69.3 \%$ \\
Objective & & \\
Bonett index of lipodystrophy & 18 & \\
\hline
\end{tabular}

\section{TABLE 3}

Adequacy of the anthropometric measurements calculated with the 50th percentile of the reference values in percentile tables presented by Frisancho (1990).

\begin{tabular}{lcccc} 
& $\begin{array}{c}<\mathbf{7 0 \%} \\
\text { adequation }\end{array}$ & $\begin{array}{c}\mathbf{7 0 - 9 0 \%} \\
\text { adequation }\end{array}$ & $\begin{array}{c}\mathbf{9 0}-\mathbf{- 1 1 0 \%} \\
\text { adequation }\end{array}$ & $\begin{array}{c}>\mathbf{1 1 0} \% \\
\text { adequation }\end{array}$ \\
\hline $\mathrm{AC}(\mathrm{cm})$ & $1(3,8 \%)$ & $6(34,5 \%)$ & $9(34,6 \%)$ & $3(11,5)$ \\
TSF $(\mathrm{mm})$ & $19(73,0 \%)$ & $1(3,8 \%)$ & $4(15,3 \%)$ & $1(3,8 \%)$ \\
AMC $(\mathrm{cm})$ & $0(0 \%)$ & $7(36,8 \%)$ & $12(46,1 \%)$ & $7(26,9 \%)$ \\
AFA $(\mathrm{cm} 2)$ & $20(76,9 \%)$ & $0(0 \%)$ & $3(11,5 \%)$ & $3(11,5 \%)$
\end{tabular}

AC: arm circumference; TSF: triceps skinfold; AMC: arm muscle circumference; AFA: arm fat area. 
is due to the long duration of HAART (26). In another study on HIV-seropositive patients, Hodgson detected a $34 \%$ prevalence of pre-obesity and a $9 \%$ prevalence of obesity (27).

Differing from our study, in a Danish cohort of HIVseropositives patients, increased in blood pressure were found in 51\% (28). In this cohort, $44 \%$ of the patients had hypertrigliceridemia, low concentration of HDL cholesterol were present in 39\%, 21\% had abdominal obesity and $16 \%$ had changes in fasting glucose.

It is recognized that metabolic disorders more common among patients on antirretroviral treatment are dyslipidemia followed by changes in carbohydrate metabolism and insulin resistence, which is consistent with the data in this study (29).

Subjective evaluation revealed that lipoatrophy most commonly occurs in the leg (69.3\%) and lipohypertrophy most commonly occurs in the abdomen (80.7\%). Single lipoatrophy and lipohypertrophy regions were present in a small portion of the subjects studied, with most of these patients presenting mixed alterations. A prospective analysis that followed up 366 seropositive patients for one year starting from the time when they began HAART demonstrated a cumulative incidence of $29 \%$ for lipoatrophy, 23\% for lipohypertrophy, and 13\% for the mixed form of lipodystrophy (30).

Bonnet et al. (18) proposed an easy and objective method for the definition of lipodystrophy based on the evaluation of body composition by DXA, i.e., the fat mass index. In their study they assessed a population of 241 HIV-seronegative men and of 162 seropositive men, including 34 patients receiving no HAART and 128 receiving HAART, with or without clinical lipodystrophy. The two main reasons for the proposal of this index were that $80 \%$ of the fat mass of the trunk is visceral and $98 \%$ of the fat mass in the limbs is subcutaneous and that the lipodystrophy syndrome associated with HIV may be the result of a loss of subcutaneous fat, an accumula-

\section{TABLE 4}

\section{Correlation between anthropometric variables and composition per body segment obtained by DXA.}

$(\mathbf{n}=26)$

Triceps skinfold and arm fat (kg) DXA

Triceps skinfold and \% arm fat DXA

Waist circumference and trunk fat (kg) DXA

Waist circumference and \% trunk fat DXA

Calf circumference and leg fat $(\mathrm{kg})$ DXA

Calf circumference and \% leg fat DXA

Thigh circumference and leg fat DXA

Thigh circumference and \% leg fat DXA
$\mathbf{R}$

0.605

0.833

0.833

0.583

0.328

0.133

0.482

0. 367 $\mathbf{p}$

$<0.01$

$<0.01$

$<0.01$

$<0.01$

0.10

0.51

$<0.01$

0.06

R: Pearson coefficient

Significant $\mathrm{p}<0.05$

TABLE 5

Concordance between the DXA and BIA methods.

Method

$\%$ arm fat $(\mathrm{n}=19)$

$\%$ trunk fat $(\mathrm{n}=20)$

$\%$ leg fat $(n=20)$

Total fat mass $(\mathrm{kg})(\mathrm{n}=26)$
St. Laurent Coefficient

0.326

0.403

0.419

0.626
0.215

0.260

0.264

0.454
$95 \%$ CI
0.525

0.589

0.559

0.760 
tion of visceral fat mass, or both. The limit chosen to define lipodystrophy by DXA was 1.5 , corresponding to 1 standard deviation above the mean index for HIVnegative men. In the present study comparing the two method for the classification of lipodystrophy (subjective and objective) the subjective classification indicated a $96.1 \%$ rate of patients with lipodystrophy and the objective one (Bonnet index) indicated a $69.3 \%$ rate. In this respect, the use of this index as an objective diagnosis using DXA was not as efficient in detecting the presence of lipodystrophy as the subjective one, although cut-off criteria would be necessary to compare these diagnosis and to determine which one World be the more reliable.

A higher prevalence of obesity was observed among women. In a prospective cohort study conducted on HIVpositive patients on HAART, central obesity was also more frequent among women than among men (31). This sex difference was also observed in the Nutritional and Health Survey conducted in the municipality of Rio de Janeiro, Brazil, which showed that $41.6 \%$ of women and $19.8 \%$ of men aged 25 to 45 years presented abdominal obesity assessed by the waist/hip ratio (32).

It should be pointed out that the classification of both BMI and WC is based on the associated risk of comorbidities, and these two anthropometric measurements are highly correlated (33). The prevalence of abdominal obesity was higher than total overweight assessed by BMI. This finding confirms the reports of body fat concentration in central regions of the body such as trunk and abdomen in HIV-seropositive patients on HAART (34).

RHC was higher than the limit values in large part of the patients evaluated (65.4\%). Its use is interesting, especially by showing morphological changes such as reduced hip circumference accompanied by increased WC, although it should be considered with caution because the hip circumference involves more errors of measurement (19).

The mean WC values of approximately $90 \mathrm{~cm}$ were compatible with those observed in patients on HAART by Visnegarwala et al. (35) and by Vassimon et al. in a previous study conducted at the same site (36).

In the present study, $42.3 \%$ of the subjects had above normal WC. The increased WC is associated with the risk for various chronic diseases, especially cardiovascular diseases, type II diabetes mellitus and certain types of cancer (33).

Other points that call attention are the high prevalences of patients with TSF and AFA inadequacy, which indicate the presence of lipoatrophy of the upper limbs.

Regarding the assessment of body composition, the present study is based on the comparison with the gold standard (DXA), which is widely employed to assess changes due to its precision, reproducibility, good correlation with computed tomography and considered an accurate method for estimating body fat mass in HIV-infected patients (37), although its cost is high and its application in clinical practice is difficult (38). The main result of the present study was the correlation of TC, WC and TSF with DXA. The SFs, circumferences and BIA are methods routinely used in the clinical area for the assessment of body composition (39).

According to Lohman et al.(19), for a predictive technique to be valid when compared to a gold standard, the correlation coefficient should be higher than 0.80 . In the present study, both TSF and WC reached these levels of correlation with percent arm fat and percent trunk fat (kg) measured by DXA, respectively.

Regarding TSF, a study by Jacobson et al. (40) showed a high correlation with both DXA and computed tomography, and therefore the measurement of this skinfold could be useful for the monitoring of subcutaneous fat in clinical routine.

In the present study we observed a significant positive correlation of TC with percent leg fat measured by DXA, but the correlation coefficient was not very high due to the small sample size. Studies correlating TC in HIV-infected patients are not available thus far. The leg is the site most affected by lipodystrophy and therefore the circumferences of this site may be useful for patient monitoring. Only studies with CfC are available in the literature, especially regarding the elderly, although with the objective of classifying signs and symptoms of undernutrition, with a cut-off point of $31 \mathrm{~cm}$ (41).

According to Guedes (42), there are more than 93 points for the measurement of skinfolds in the body. In the present study, we analyzed folds that are representative of the subcutaneous fat of arm, trunk and limbs, frequently used in anthropometry studies (43).

The comparison of the BIA and DXA methods showed that the estimate by total BIA showed more concordance compared to segmental BIA, being more appropriate when the equation validated for this group of patients is used (14). However, the estimate of body composition by segment using segmental BIA was inadequate, probably due to the fact that the predictive equations have been elaborated for individuals with normal distribution of body fat $(22,23)$.

Few studies are available in the literature comparing methods for the assessment of body composition and attempting to define specific directives for individuals with lipodystrophy syndrome, with conflicting results (44).

The present study emphasizes the importance of longitudinal follow-up with anthropometric measure- 
ments in HIV-seropositive patients with lipodystrophy syndrome. However, precise equations must be elaborated from these measurements, including segmental BIA for the assessment of the amount of fat per body segment and for an optimal clinical treatment of this specific group.

\section{RESUMEN}

Introducción: Se ha descrito cambios en la composición corporal de pacientes infectados por VIH, tales como la lipoatrofia en ciertas regiones del cuerpo y lipohipertrofia en otros, en representación de las características del síndrome de lipodistrofia. Es importante controlar la cantidad de grasa corporal por segmento utilizando métodos prácticos y de bajo costo con el fin de optimizar el tratamiento de este grupo. Objetivos: correlacionar la composición corporal por segmento corporal obtenidos por las mediciones antropométricas y por impedancia bioeléctrica com DXA segmentaria en pacientes seropositivos al VIH en tratamiento antirretroviral. Métodos: Se midieron las circunferencias de brazo, cintura, cadera, muslo y pantorrilla y los pliegues cutáneos: bíceps, tríceps, subescapular, suprailíaco) y se realizaron impedancia bioeléctrica segmentaria (BIA) el análisis y DXA. La prueba de Pearson se utilizó para determinar las correlaciones y la prueba de San Lorenzo se utilizó para evaluar la concordancia entre las variables. Resultados: Se evaluaron 26 pacientes, 35\% de los cuales tenían sobrepeso. El pliegue del tríceps (PT), circunferencia de la cintura (CC) y la circunferencia del muslo (CM) se correlacionaron significativamente con la medida obtenida por el patrón de oro ( $\mathrm{p}<0.01$ ). No hubo concordancia entre los valores obtenidos por BIA y DXA segmentaria. Conclusiones: Las mediciones antropométricas como PT, CC y CM son importantes para el seguimiento de los cambios en la composición corporal de los pacientes infectados por VIH que reciben tratamiento antirretroviral. La BIA segmental no demostró ser adecuado para la evaluación de la composición corporal en pacientes infectados por VIH.

Palabras clave: antropometría, impedancia bioeléctrica segmentaria, lipodistrofia, VIH.

Dirigir la correspondencia a:

Profesora

Rebeca Antunes Beraldo

Endereço residencial: Rua Maestro Enrico Ziffer,105

Bairro: Jardim Paulistano

Cep: 14090-347 Ribeirão Preto-SP, Brasil

Fax: (16)3602-3095

E-mail: rebecaberaldo@yahoo.com.br

\section{REFERENCES}

1. Fauci AS. HIV and AIDS.: 20 years of science. Nat Med, 2003, 9(7): 839-43.

2. Potthoff A, Brocmeyer NH, Gelbrich G, Neuhaus K, Stefa E, Reinsch N, et al. Lipodystrophy -a sing for metabolic syndrome in patients of the HIV-HEART study. J Dtsch Dermatol Ges 2010, 8:92-8.

3. Wand H, Calmy A, Carey DL, Samaras K, Carr A, Law MG et al. Metabolic syndrome, cardiovascular disease and type 2 diabetes mellitus after initiation of antiretroviral therapy in HIV infection. AIDS 2001, 21(18):2445-53.

4. Torriani M, Thomas BJ, Barlow RB, Librizzi J, Dolan S, Grinspoon S. Increased intramyocellular lipid accumulation in HIV-infected women with fat redistribution. J Applied Physiology (Bethesda), 2006;100 (2) 609-14.

5. Batterham MBD, Garsia R. Nutritional management of HIV/AIDS in the era of highly active antiretroviral therapy: a review. Australian J Nutr Diet 2001;58, (4)p. 211-23.

6. Bedimo RJ. Body-Fat Abnormalities in Patients With HIV: Progress and Challenges. J Int Assoc Physicians AIDS Care (Chic Ill) 2008; 7:292-305.

7. Walton C, Lees B, Crook D, Godsland If, Stevenson Jc. Relationships between insulin metabolism, serum lipid profile, body fat distribution and blood pressure in healthy men. Atherosclerosis 1995;118(1): 35-43.

8. Von Eyben FE, Mouritsen E, Holm J, Montvilas P, Dimcevski G. Intraabdominal obesity and metabolic risk factors: a study of young adults. Int J Obes 2003, 27(8): 941-9.

9. Moore FD, Olesen KH, McMurrey JD, Parker HV, Ball MC, Boyden CM: The body cell mass and its supporting environment, in Body Composition Analysis in Health and Disease, Philadelphia, W.B. Saunders, 1963, p 1484-508.

10. Kotler DP, Tierney AR, Wang J, Pierson RN. Magnitude of bodycell-mass depletion and the timing of death from wasting in AIDS. Am J Clin Nutr 1989; 50: 444-7.

11. Oppliger RA, Nielsen DH, Shetler AC, Crowley ET, Albright JP. Body composition of collegiate football players: bioelectrical impedance and skinfolds compared to hydrostatic weighing. J Orthop Sports Phys Ther 1992; 15(4):187-92.

12. Kyle UG, Bosaeus I, De Lorenzo AD, Deurenberg P, Elia M, Gomez JM, Heitmann BL, Kent-Smith L, Melchior JC, Pirlich M, Scharfetter H, Schols AM, Pichard C. Bioelectrical impedance analysis-part I: review of principles and methods. Clin Nutr 
(Kidlington) 2004; 23 (5):1226-43.

13. Kushner RF. Bioelectrical impedance analysis: a review of principles and applications. J Am Coil Nutr, 1992, 1 1:199-209.

14. Kotler DP, Burastero S, Wang J, Pierson Jr RN. Prediction of body cell mass, fat-free mass, and total body water with bioelectrical impedance analysis: effects of race, sex, and disease. Am J Clin Nutr (Bethesda), 1996; 64, (3) 489S - 97S.

15. Baumgartner RN, Chumlea WC, Roche AF. Estimation of body composition from bioelectric impedance of body segments. Am J Clin Nutr 1989, 50: 221-6.

16. Nicholas IP, Ma MRCP, Marinos Elia MD, Graham J, Leigh CW, George E. Griffin, Phd, Frcp. Bioelectrical impedance analysis in human immunodeficiency virus-infected patients: comparison of single frequency with multifrequency, spectroscopy, and other novel approaches. Nutrition 1998; 14: 658-66.

17. Sutinen J, Yki-Jarvinen H. Increased resting energy expenditure, fat oxidation, and food intake in patients with highly active antiretroviral therapyassociated lipodystrophy. American journal of physiology. Endocrinol Metab (Bethesda); 2007; 292, (3): 687-92.

18. Bonnet E, Delpierre C, Sommet A. Total body composition by DXA of 241 HIV-negative men and 162 HIV-infected men. J Clin Densitom 2005; 8:287-92.

19. Lohman TG, Roche AF, Martorell R. Anthropometric standardization reference manual. Abridged edition, 1991, p. 90.

20. Frisancho AR. Triceps skinfold and upper arm muscle size norms for assessmemt of nutritional status. Am J Clin Nutr 1974, 27: 1052-58.

21. Frisancho AR. Anthropometric standards for the assessment of growth and nutritional status.University of Michigan, 1990, p.189.

22. Chumlea Wc, Baumgartner Rn, Roche Af. Specific resistivity to estimate fat free mass from segmental body measures of bioelectric impedance. Am J Clin Nutr 1988; 48: 7-15.

23. Baumgartner Rn, Chumlea Wc, Roche Af. Estimation of body composition from bioelectric impedance of body segments. Am J Clin Nutr 1989; 50: 221-6.

24. St Laurent RT. Evaluating Agreement with a Gold Standard in Method Comparison Studies. Biometrics 1998; 54: 537-45.

25. SAS/STAT ${ }^{\circledR}$ User's Guide, Version 9, Cary, NC, USA: SAS Institute Inc., 2002า-2003.

26. Boskurt B. Cardiovascular toxicity with highly active antiretroviral therapy: review of clinical study.
Cardiovasc Toxicol 2004;4(3):243-60.

27. Hodgson TA. HIV-associated oral lesions: prevalence in Zambia. Oral Diseases 1997, 3: 46-50.

28. Hansen BR, Petersen J, Haugaard SB, Madsbad S, Obel N, Suzuki Y et al. The prevalence of metabolic syndrome in Danish patients with HIV infection: the effect of antiretroviral therapy. HIV Méd 2009, 10(6):378-87.

29. Fichtenbaum CJ. metabolic abnormalities associated with hiv infection and antiretroviral therapy. Curr Infect Dis Rep. 2009; 11(1):84-92.

30. Heath K, Chan KJ, Singer J, et al. Incidence of morphological and lipid abnormalities: Gender and treatment differentials after initiation of first antiretroviral therapy. Intern J Epidemiol 2002, 31:1016-20.

31. Martinez E, Mocroft A, García-Viejo MA, PérezCuevas JB, Blanco JL, Mallolas J. Risk of lipodystrophy in HIV-1-infected patients treated with protease inhibitors: a prospective cohort study. Lancet 2001; 357(9256): 592-8.

32. Pereira AR. Avaliação antropométrica do estado nutricional. In: Sichieri R. Epidemiologia da obesidade.Rio de Janeiro; EdUERJ, 1998, p. 43-63.

33. World Health Organization (WHO). Diet, nutrition and the prevention of chronic diseases. Report of a joint WHO/FAO expert consultation. Geneva; WHO $\neg$ Technical Report Series, 2003, 916.

34. Mcdermott AY, Shevitz A, Knox T, Roubenoff R, Kehayias J, Gorbach S. Effect of high active antiretroviral therapy on fat, lean, and bone mass in HIVseropositive men and women. Am J Clin Nutr 2001; 74(5): 679-86.

35. Visnegarwala F, Raghavan SS, Mullin CM, Bartsch G, Wang J, Kotler D, Gibert CL, Shlay J, Grunfeld C, Carr A, El-Sadr W. Sex differences in the associations of HIV disease characteristics and body composition in antiretroviral $\neg$ naive persons. Am J Clin Nutr, Bethesda, 2005; 82, (4) 850-6.

36. Vassimon HS, Deminice R, Machado AA, Monteiro JP, Jordao Jr AA. The Association of Lipodystrophy and Oxidative Stress Biomarkers in HIV-Infected Men. Current HIV Research (Print), 2010; 8: 364-9.

37. Aghdassi E, Arendt B, Salit IE, Allard JP. Estimation of body fat mass using dual-energy x-ray absorptiometry, bioelectric impedance analysis, and anthropometry in HIV-positive male subjects receiving highly active antiretroviral therapy. JPEN J Parenter Enteral Nutr 2007; 31 (2): 135-41.

38. Valerio CM, Godoy-Matos A, Moreira RO, Carraro L, Guedes EP, Moises RS, Mory PB, De Souza LL, 
Russo LA, Melazzi A C. Dual-energy X-ray absorptiometry study of body composition in patients with lipodystrophy. Diabetes Care 2007; 30 (7)1857-9.

39. Schwenk A. Methods of assessing body shape and composition in HIV associated lipodystrophy. Curr Opin Infect Dis 2002;15 (1)9-16.

40. Jacobson DL, Knox T, Spiegelman D, Skinner S, Gorbach S, Wanke C. Prevalence of, evolution of, and risk factors for fat atrophy and fat deposition in a cohort of HIV-infected men and women. Clinical infectious diseases : an official publication of the Infectious Diseases Society of America, Chicago, 2005; 40:1837-45.
41. Busnello FM. Aspectos nutricionais no processo do envelhecimento. 1 ed. São Paulo (SP): Atheneu, 2007.

42. Guedes DP. Composição corporal: princípios, técnicas e aplicações. 2a ed. Londrina: APEF; 1994

43. Heyward VH, Stolarczk IM. Avaliação da composição corporal aplicada. São Paulo: Manole; 2000.

44. Wanke C, Polsky B, Kotler D. Guidelines for using body composition measurement in patients with human immunodeficiency virus infection. AIDS Patient Care STDS, Larchmont, 2002, v. 16, n. 8, p. 375-88. 